\title{
Rates and Methods of Rice Straw Application to Wheat and Rice Crops and the Implications on Crop Productivity as Well as some Soil Properties
}

\author{
A.M.G. Ewis, M.M. Sobh, M.H. Amer and M. Gouda \\ Soil and Water Department, Faculty of Technology and \\ Development, Zagazig Univerity, Zagazig, Egypt.
}

\begin{abstract}
7 WO FIELD experiments one on wheat and one on rice succeeding wheat (2009/2010 wheat, 2010 rice) were carried out on a clayey soil at Ghazala El-khis on Efficient Productivity Institute farm, Sharkhia-Governorate to study the effect of rice straw residue applied to wheat on yield and nutrient uptake of wheat and also the residual effect of such residues on rice crop which succeeded the wheat crop. Rates were 4.8, 9.5 and 14.3 Mg (mega grams) $\mathrm{ha}^{-1}$, methods were surface application followed by incorporation in the $30 \mathrm{~cm}$ top soil, and application in ditches $40 \mathrm{~cm}$ deep (tunnels) spaced at 2,3and $4 \mathrm{~m}$ between each other. Application of straw caused slight decrease in wheat grains and marked decreases in straw yields. Ditch application recorded greater values over surface application. Uptake of $\mathrm{N}$ and $\mathrm{P}$ by wheat was lower due to rice residue application but for $\mathrm{K}$, it gave higher values over the nontreated and the highest values were recorded at the $3^{\text {rd }}$ rate with ditches treatment of $2 \mathrm{~m}$ distance. There was a residual effect on yields of rice as well as NPK uptake and protein percent over treatment not receiving rice straw residue in the preceding wheat crop. The ditch method was superior to the broadcast method; and decreased with increasing the spacing between ditches, as well with the decrease in the rate of application. The results also indicated positive effects on bulk density as well as organic matter and NPK contents in soil. Greater values were obtained at the rate of the 14.3 $\mathrm{Mg} \mathrm{ha}^{-1}$ with ditches method of $2 \mathrm{~m}$ distances.
\end{abstract}

Keywords: Wheat plants, Rice plants, Residual effect, Straw residue, Ditches.

Crop residues are regarded as waste materials that require disposal, but they are important natural material resources and not wastes. Incorporation of cereal straws of wide $\mathrm{C}$ : $\mathrm{N}$ ratio, immobilizes soil $\mathrm{N}$ and adversely affects yield of the succeeding crop (Sidhu and Beri, 1989). Rice straw left in the field after harvesting is generally burnt by many farmers in Egypt, although contains nutrients. Burning these residues cause loss of organic matter and plant nutrients and environmental pollution. Verma and Bhagat (1992) reported that rice straw had positive effects on rice yield and $\mathrm{N}$ uptake. Tawfic and Gomaa (2005), Zeidan et al. (2005) and Yaduvanshi \& Sharma (2008) reported that farmyard manure application enhanced wheat yield and $\mathrm{N}, \mathrm{P}$ and $\mathrm{K}$ uptake. Niveta et al. (2006) reported that mineral fertilizers gave higher yield of wheat than rice. 
Gong et al. (2009) and Liu et al. (2010) showed that, long term addition of organic manure showed beneficial effects on wheat and maize. Application of organic materials to wheat crop gave significant increases in grain and straw yields, crop index, harvest index, and N, P and K uptake. Crop residues convert farm wastes into useful products and provide nutrients for crops, and maintain soil physical and chemical conditions (Powel and Unger, 1997 and Jimenez et al., 2002) Incorporation of rice straw and animal manure in soil increased organic matter, available $\mathrm{N}, \mathrm{P}, \mathrm{K}, \mathrm{Zn}, \mathrm{Cu}, \mathrm{Fe}$ and $\mathrm{Mn}$ and improved soil aggregation, porosity and bulk density (Verma and Bhagat, 1992). Sarwar et al. (2008) reported that $\mathrm{pH}$ and SAR decreased due to addition of composted organic residues, also available $\mathrm{N}, \mathrm{P}, \mathrm{K}, \mathrm{Ca}$ and $\mathrm{Mg}$ as well as organic content increased. Burning rice straw causes black clouds in Egypt which would lead to respiratory problems to humans. The current study was conducted to study the effect of rice straw application to the soil on wheat productivity and the residual effect on the succeeding rice crop and soil properties in Sharkhia Governorate.

\section{Material and Methods}

A field experiment was carried out with rice and wheat (season 2009-2010) and the succeeding crop of rice (season 2010) at the farm of Faculty of Technology and Development (Ghazala El-Khis) - Sharkia Governorate to study the effect of rice straw application on wheat crop and the residual effect on the succeeding rice crop. Main characteristics of the soil and the rice straw residues are recorded in Table 1 . The treatments were replicated thrice in a split plot design. The main plots were assigned to the rate of straw application (4.8, 9.5 and 14.3 $\mathrm{Mg} \mathrm{ha}^{-1}$ ). The sub plots were assigned to the method of application (surface incorporation into the $30 \mathrm{~cm}$ top layer and deep application in $40 \mathrm{~cm}$ deep at distances of 2-, 3-and 4- $\mathrm{m}$ each tunnel treatment). An additional treatment without straw application was done. The area of the experimental plot was $48 \mathrm{~m}^{2}$. The straw residues were cut by a machine to obtain parts with high surface area. Chemical fertilizers were added to the residues at recommended NPK doses. Phosphorus at $17 \mathrm{~kg} \mathrm{P}$ as super phosphate $(6.8 \% \mathrm{P})$ and $48 \mathrm{~kg} \mathrm{~K}$ in the form of potassium sulfate $(40 \% \mathrm{~K}) \mathrm{ha}^{-1}$, respectively were added to each crop. For nitrogen, $214 \mathrm{~kg} \mathrm{~N}$ as urea $(46.5 \% \mathrm{~N})$, and $179 \mathrm{~kg} \mathrm{~N}$ as ammonium sulfate $(21 \% \mathrm{~N})$ were applied for wheat and rice, respectively. $\mathrm{P}$ and half $\mathrm{K}$ rates were added before wheat sowing or rice transplanting, the other $\mathrm{K}$ half was given with the second $\mathrm{N}$ split. Nitrogen was added in three equal splits at planting, 30 days after sowing and 60 days after sowing for wheat, for rice nitrogen splits were before transplanting, 30 days after transplanting and 45 days after transplanting.

Seeds of wheat (Triticum aestivum L., cv Sakha 93) were seeded on $30^{\text {th }}$ of November, 2009, broadcast at a rate of $143 \mathrm{~kg} \mathrm{ha}^{-1}$. seedlings of rice (Oryza sativa L., cv Sakha 101) were transplanted on $15^{\text {th }}$ July, 2010, 2-3 seedlings hill ${ }^{-1}$ at $15 \mathrm{~cm} \times 20 \mathrm{~cm}$. Recommended cultural practices were followed to raise the crops of wheat and rice. The crops were harvested at maturity, and yields were recorded. Plant samples were taken and analyzed for NPK. After rice harvest, composite soil samples from the $20 \mathrm{~cm}$ top layer from each plot were collected and analyzed. Analysis of samples as well as soil were determined according to

Egypt. J. Soil Sci. 54, No. 1 (2014) 
Chapman and Pratt (1961).Soil particle size distribution and other physical analysis were done according to Piper (1950).

TABLE 1. Physicochemical analysis of tested soil and chemical properties of rice straw residue.

\begin{tabular}{|c|c|c|c|c|c|c|c|c|c|c|c|}
\hline \multicolumn{11}{|c|}{ Analysis of soil of the experimental site } & \multirow[b]{2}{*}{$\begin{array}{c}\text { Available } \\
\text { K } \\
\text { Mgkg }^{-1} \\
\end{array}$} \\
\hline $\begin{array}{c}\text { Fine } \\
\text { sand } \%\end{array}$ & \begin{tabular}{|c|c|}
$\begin{array}{c}\text { Coarse } \\
\text { sand } \\
\%\end{array}$ \\
\end{tabular} & Silt \% & $\underset{\%}{\text { Clay }}$ & $\begin{array}{c}\text { Textural } \\
\text { class }\end{array}$ & $\underset{\left(\mathbf{d S m}^{-1}\right)}{\mathbf{E C}}$ & $\underset{\left(\mathrm{gKg}^{-1}\right)}{\mathrm{OM}}$ & $\underset{\%}{\mathrm{CaCO}}$ & \begin{tabular}{|c|} 
Total \\
$\mathbf{N}$ \\
$\left(\mathrm{gkg}^{-1}\right)$ \\
\end{tabular} & $\begin{array}{c}\text { Available } \\
\mathbf{N} \\
\text { mgkg }^{-1} \\
\end{array}$ & \begin{tabular}{|c|} 
Available \\
P \\
Mgkg $^{-1}$ \\
\end{tabular} & \\
\hline 11.2 & 5.8 & 20.4 & 62.6 & Clay & 1.10 & 18.30 & 2.20 & 1.23 & 160 & 19 & 290 \\
\hline \multicolumn{11}{|c|}{ Chemical properties of rice straw residue } & \\
\hline \multicolumn{4}{|c|}{ OC $\left(\mathrm{g} \mathrm{kg}^{-1}\right)$} & $\mathrm{C} / \mathrm{N}$ ratio & \multicolumn{3}{|c|}{ Total N ( $\left.\mathrm{g} \mathrm{kg}^{-1}\right)$} & \multicolumn{2}{|c|}{ total $P\left(\mathrm{~g} \mathrm{~kg}^{-1}\right)$} & \multicolumn{2}{|c|}{ total $\mathrm{K}\left(\mathrm{g} \mathrm{kg}^{-1}\right)$} \\
\hline \multicolumn{3}{|c|}{40.46} & & 83 & \multicolumn{3}{|c|}{0.49} & \multicolumn{2}{|c|}{0.066} & \multicolumn{2}{|c|}{1.43} \\
\hline
\end{tabular}

\section{Results and Discussion}

\section{Effect of organic residues on wheat production}

The data in Table 2 represent the wheat production under different rates of rice straw application. The addition of rice straw within all tested rates resulted in decreases in grains, and straw compared to the no-rice straw (NRO) treatment which received NPK only. On an average, the greatest value of wheat straw yield was 7.9 ton ha-1 with a decrease of $3.54 \%$ compared with the NRO treatment. In the case of tunnel treatments, data show significant differences between treatments. The main effect show greatest decrease in yield with increasing the rate of applied rice straw. Decreases were statistically nonsignificant with grains, but significant with straw. The decreases due to applying $1^{\text {st }} 2^{\text {nd }}$ and $3^{\text {rd }}$ of straw were $8.2,9.3$ and $12.9 \%$ for grain yield and 3.5, 6.1 and $9.4 \%$, respectively for straw yield. Such a pattern of decreased yields with increased application of straw occurred with all methods of application. Sidhu and Beri (1989) reported that, incorporation of cereal straws of wide C: N ratio immobilize soil $\mathrm{N}$ and adversely affected yield of crops.

Concerning to the main effect of the method of straw application, data show significant greater yields of grains and straw with ditch method compared with the surface incorporation and the greater the distance between the ditches the higher was the yield. Incorporating straw in the soil surface makes the soil plough layer subject to a greater immobilization of available $\mathrm{N}$ compared with ditch method. Besides, a straw incorporation in close-distance ditches would be subject to greater N-immobilization. These results agree with Bunt (1988), Van Kessel et al. (2000) and Qian \& Schoenau (2002), who stated that immobilization in soil occurs with organic materials of high C: $\mathrm{N}$ ratio. Cheshire et al. (1999) stated that, when straw remains in the field after harvest, its rapid decomposition is important to minimize the negative effect due to immobilization of available nutrients. Azam et al. (1991) reported that added mineral $\mathrm{N}$ following straw incorporation into the soil in order to overcome yield decrease due to $\mathrm{N}$ immobilization. 


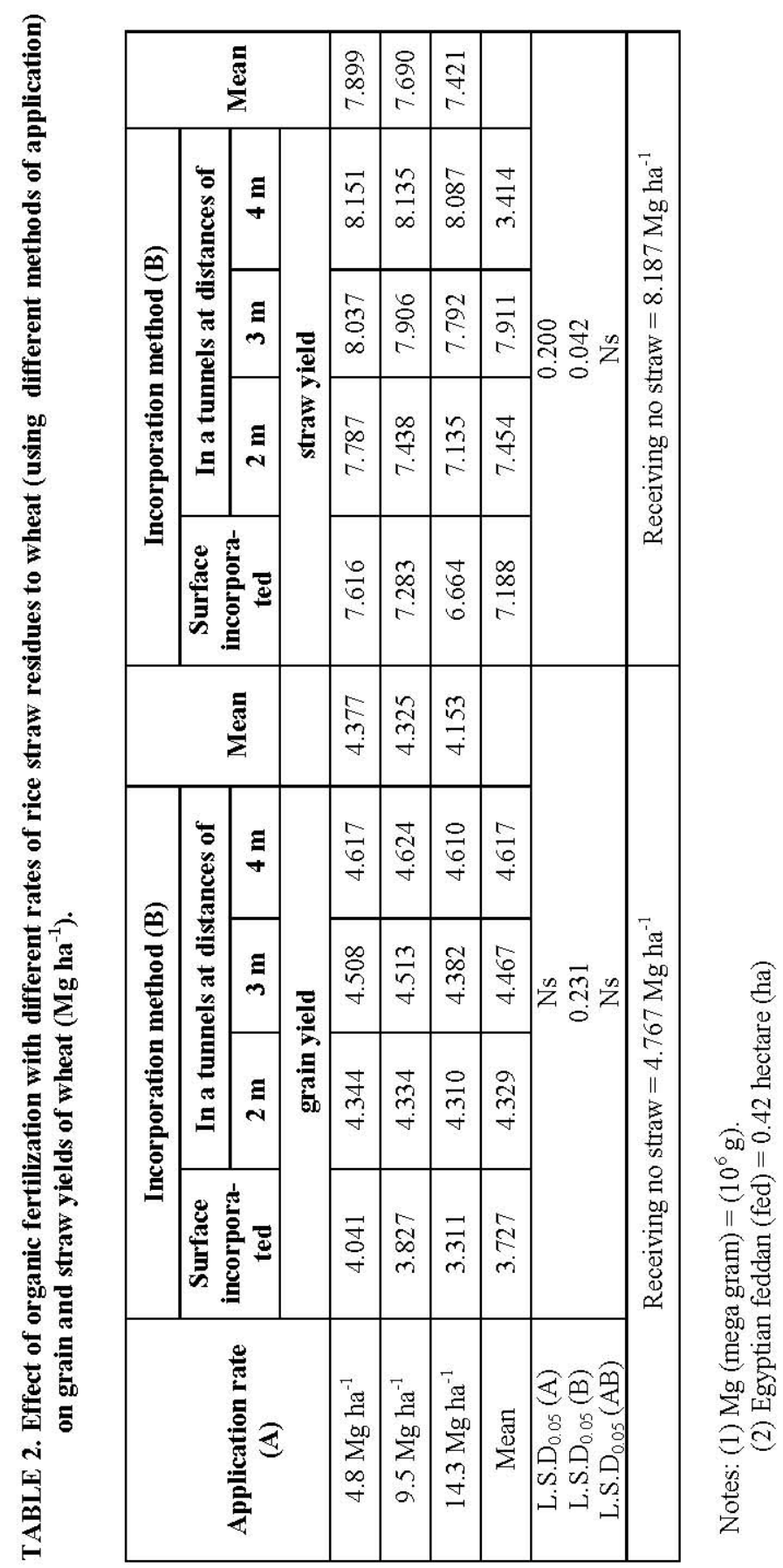

Egypt. J. Soil Sci. 54, No. 1 (2014) 


\section{Residual effect of organic residues on the succeeding rice crop}

The data in Table 3 show the residual effect of organic residues on rice production under different rates of rice straw residues with two methods of application. Addition of residues within all tested rates for all methods of application (surface as well as ditches) resulted in positive effect on grain and straw of rice. Verma and Baghat (1992), Cassman et al. (1993), Bird et al. (2001) and Kaewpradit et al. (2009) reported that straw and animal manure incorporation increased rice yields and $\mathrm{N}$ uptake. Increases obtained in the current study were associated with increases in the rate of application. The values were greater in ditches than in surface incorporation at all rates of application. Incorporation of rice straw into soil reduces $\mathrm{N}$ loss (Shindo and Nishio, 2005).

The ditch method gave higher values than the surface incorporation one. Yield of grain and straw decreased with increasing the distance between ditches. Compared with surface application, the 2- 3- and 4-m ditch distance gave average increases of $12.4,5.3$ and $4.7 \%$ for grains, respectively, increases for straw were $2.7,10.1$ and $13.0 \%$, respectively.

\section{Nutrient uptake}

Wheat crop

The N- uptake in wheat grains and straw are recorded in Tables 4 and 5. All treatments receiving rice straw contained lower $\mathrm{N}$ - uptake in wheat grain and straw compared with the treatment not receiving straw. This demonstrates marked immobilization of available $\mathrm{N}$ in the soil caused by rice straw residue. These results are in a good agreement with those of Elliot et al. (1981), Verma and Bhagat (1992), Azam et al. (1993), Soon (1999), Varendarpal Singh et al. (2006) and Sharma \& Parasad (2008) who stated that applying rice straw residue to the soil reduced $\mathrm{N}$ - uptake by wheat grain and straw due to their wide $\mathrm{C}: \mathrm{N}$ ratio which decreased the availability of $\mathrm{N}$ to growing plants through immobilization of mineral $\mathrm{N}$ forms into organic $\mathrm{N}$ forms. The current results show that $\mathrm{N}$ - uptake decreased with increasing the rate of application.

With respect to the effect of method of application, data show that, the ditch method gave greater values in $\mathrm{N}$ - uptake. The uptake increased with increasing distance between ditches. Regarding grain protein content, data in Table 6 show lower protein content in treatments of the surface incorporation as well as those of the ditch method, particularly those of the 2- and 3-m distance as compared with content in the no-straw application. Contents in the ditch method were greater than in the surface application method. Contents decreased with increasing straw -application rate. Average decreases for the $1^{\text {st }}, 2^{\text {nd }}$, and $3^{\text {rd }}$ rates were $11.5,15.3$ and $21.2 \%$, respectively. The ditch method surpassed the surface application method by averages of $16.1,25.7$, and $40.01 \%$ for the $2-$, 3 - and 4- $m$ distance, respectively. The greater the distance between ditches, the higher are the contents of protein. 


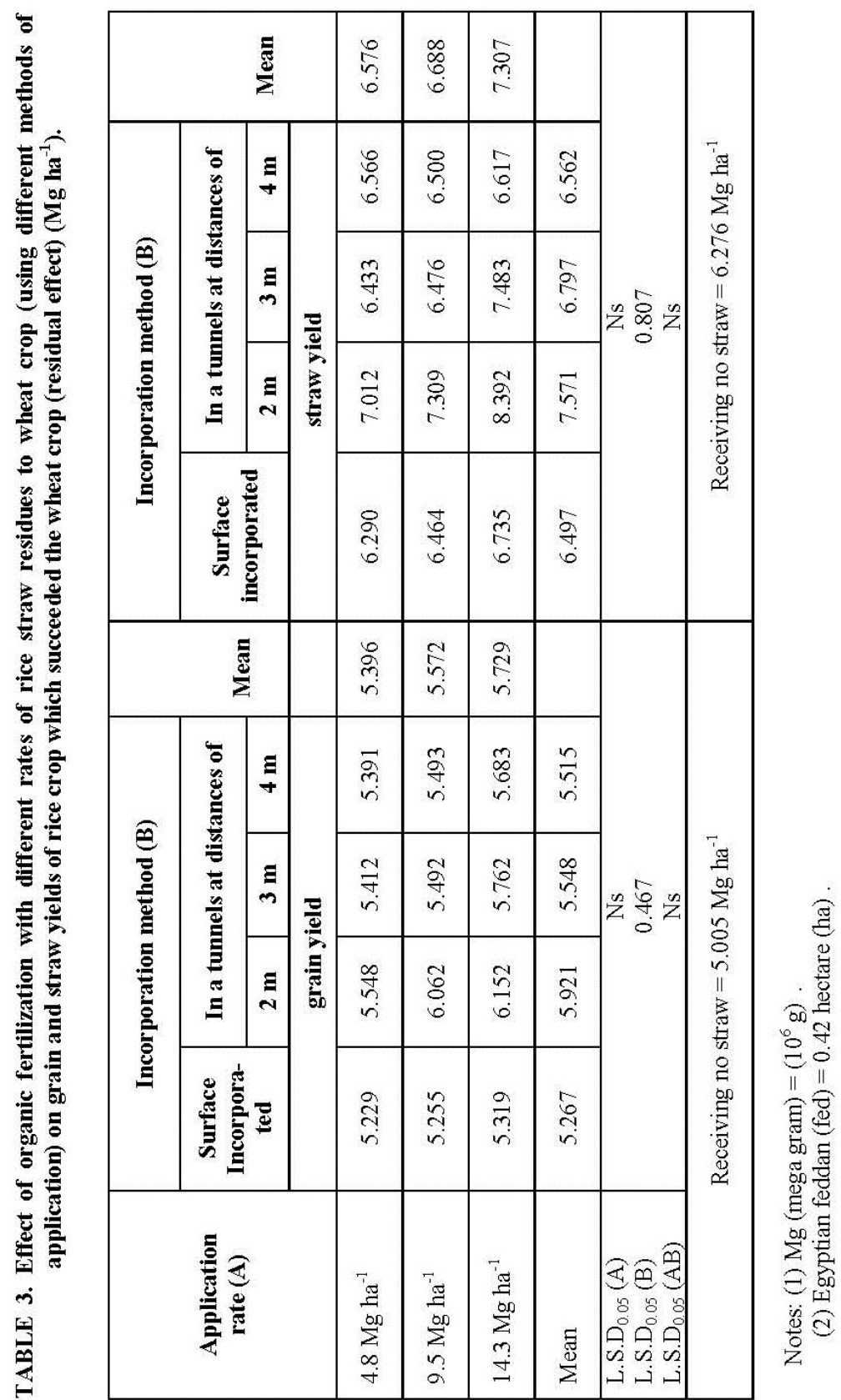

Egypt. J. Soil Sci. 54, No. 1 (2014) 
RATES AND METHODS OF RICE STRAW APPLICATION...

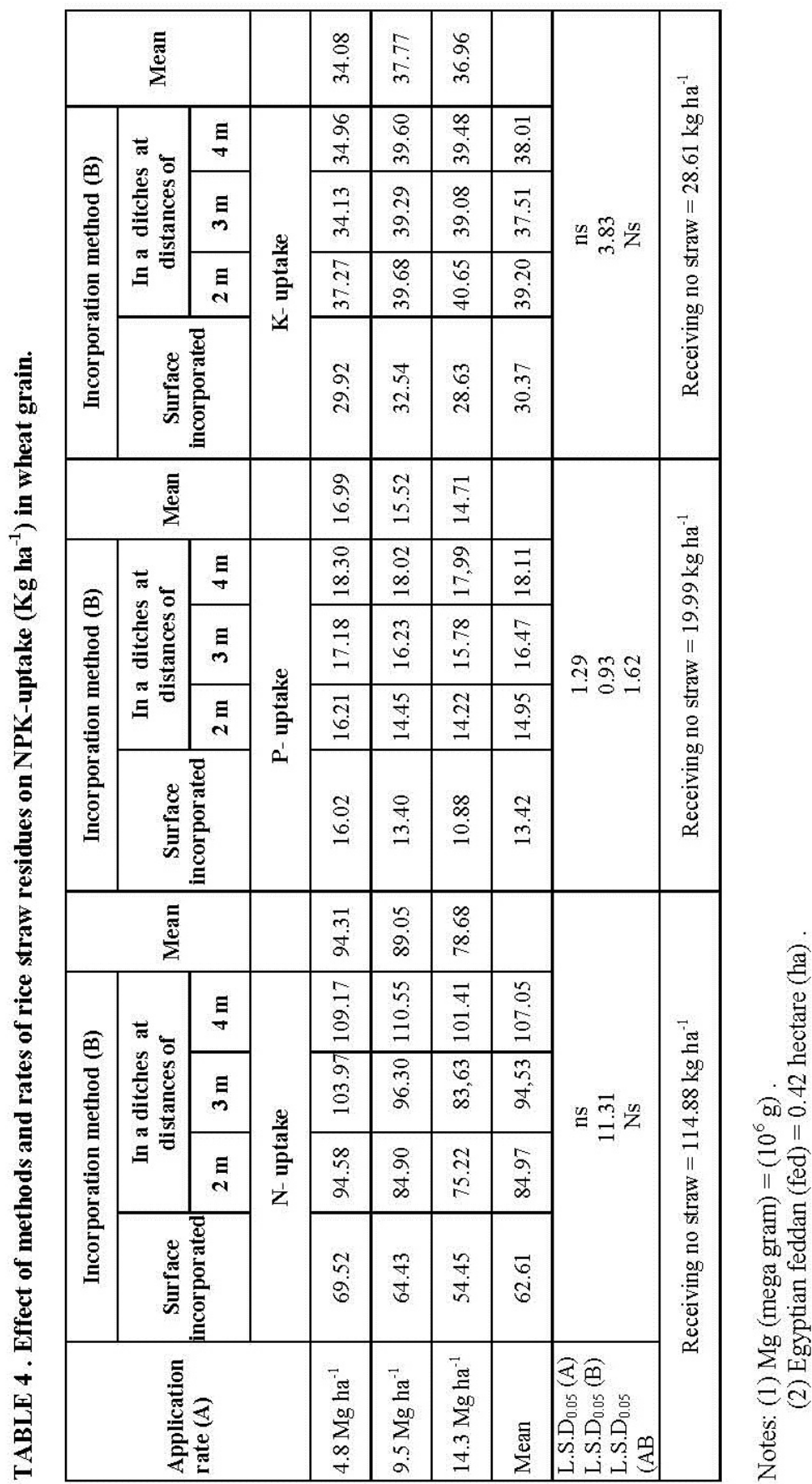

Egypt. J. Soil Sci. 54, No. 1 (2014) 


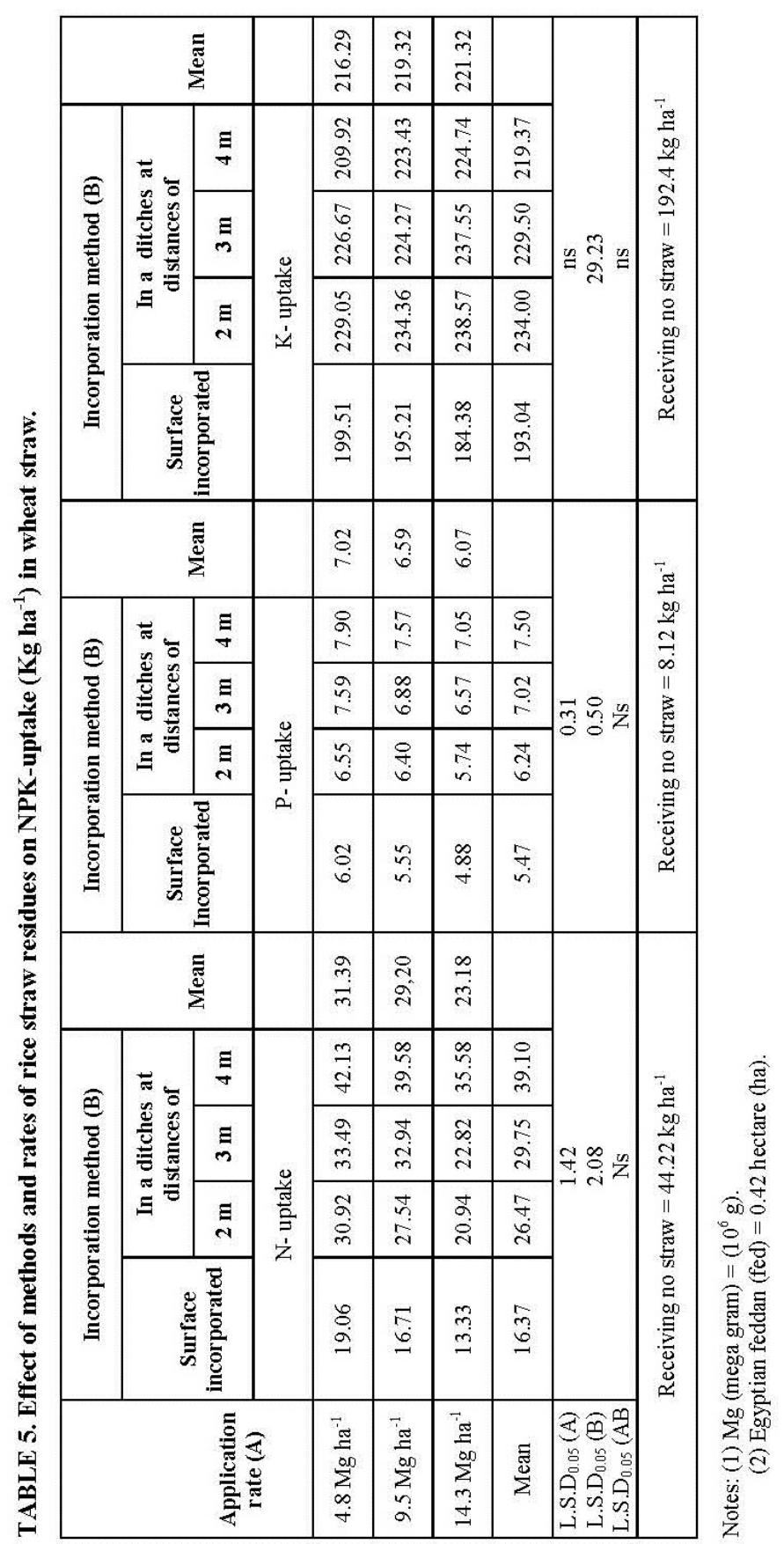

Egypt. J. Soil Sci. 54, No. 1 (2014) 
RATES AND METHODS OF RICE STRAW APPLICATION...

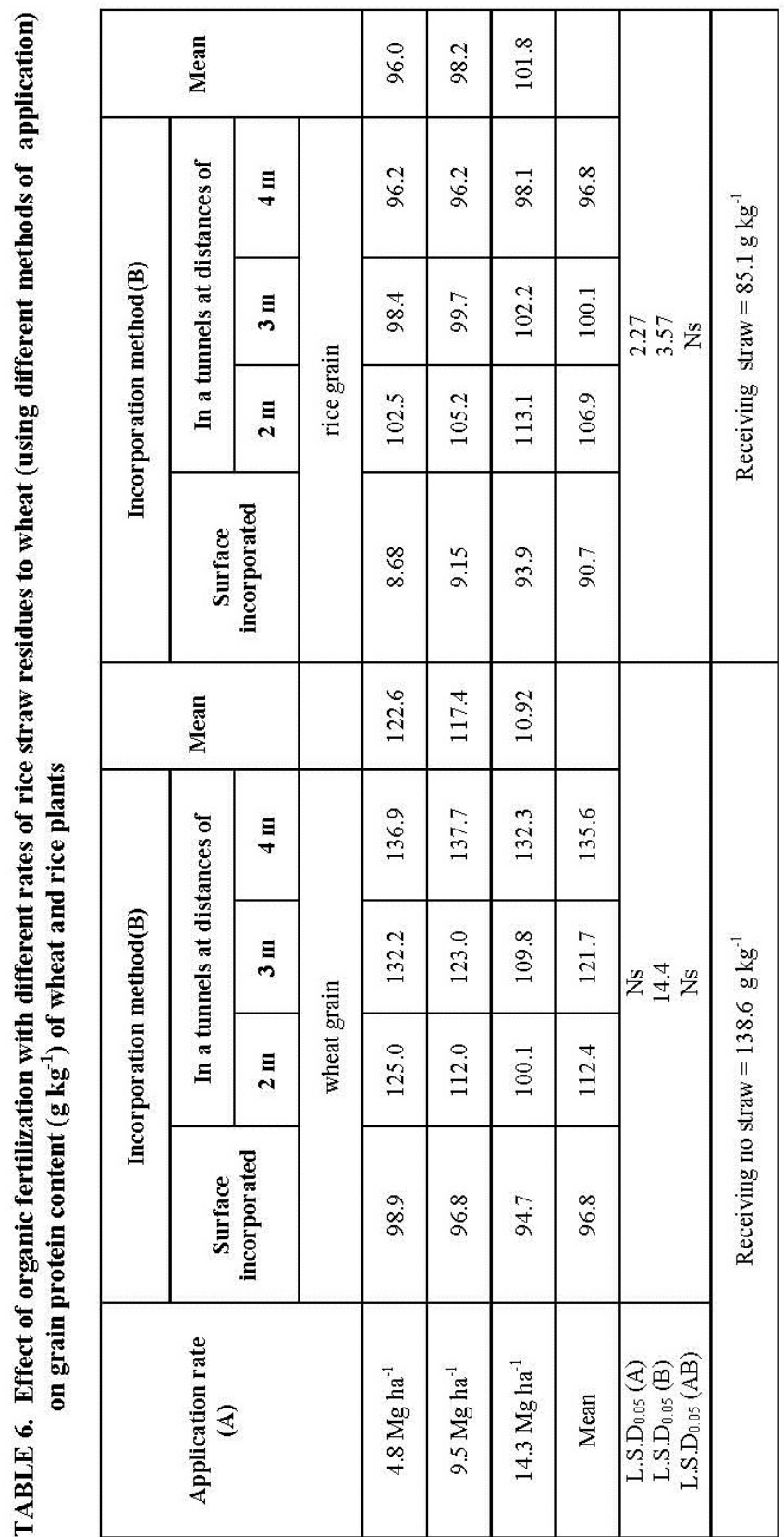

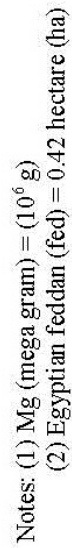

Egypt. J. Soil Sci. 54, No. 1 (2014) 
Regarding P- uptake, results are similar to those of N. Data recorded in Table 4 indicate lower $\mathrm{P}$ - uptake in treatments given rice straw compared with the treatment not receiving straw. Such a pattern is in line with that of N- uptake and indicates immobilization and decrease in available nutrients due to rice straw application. These results are in agreement with those obtained by Elliot et al. (1981), Verma and Bhagat (1992), Azam et al. (1993), Can (1999) and Varendalpal et al. (2006).

P-uptake decressed as the rate of straw application increased. The ditch method was greater compared with the surface method. P-uptake increased with increasing distance between ditches. These findings are in harmony with those obtained by Elliot et al. (1981) and Sharma \& Parasad (2008) who reported that rice straw being of wide $\mathrm{C}$ : $\mathrm{N}$ ratio reduces the availability of nutrients to growing plants through immobilization. Varinderpal et al. (2006) found that incorporation of crop residues increased $\mathrm{P}$ adsorption as well as resistance to $\mathrm{P}$ release in soils.

Data of Table 4 indicate that application of rice straw caused pronounced positive effect on wheat $\mathrm{K}$ - uptake. The uptake increased when the rate increased. Average increased at $1^{\text {st }}, 2^{\text {nd }}$ and $3^{\text {rd }}$ rates of application were 19.1, 32.0 and $29.2 \%$, respectively for uptake in grains and $12.4,14.0,15.0 \%$, respectively for uptake in straw. The ditch method surpassed the surface method by averages of $30.4,23.5$ and $25.3 \%$, respectively for K-uptake in grains and $21.2,18.9$ and $13.6 \%$ for uptake in straw.

These findings are in harmony with those obtained by Kaur and Benipal (2006). Data also reported that K- uptake decreased with increasing the distance between ditches. Increases with the 2- , 3- and 4-m spacing were 37.0, 31.1 and $32.9 \%$, respectively for $\mathrm{K}$ - uptake in grains and $21.6,19.3$ and $14.0 \%$ for $\mathrm{K}$ uptake in straw of wheat.

\section{Rice crop}

Data presented in Tables 7 and 8 illustrate the effect of applying rice straw residue to wheat on uptake of $\mathrm{N}, \mathrm{P}$ and $\mathrm{K}$ in the rice crop which succeeded the wheat. Data show higher values for all treatments as compared with the no straw treatment.

Regarding N- uptake ,increases due to $1^{s t}, 2^{\text {nd }}$ and $3^{\text {rd }}$ rates of application averaged 21.2, 28.7 and $39.6 \%$ respectively for uptake in grains; $24.0,29.1$ and $46.4 \%$, respectively for uptake in rice straw. The ditch method gave greater $\mathrm{N}$ - uptake than the surface method. The increases due to the surface method, averaged $12.2, \%$ for grains $\mathrm{N}$ - uptake and $13.2 \%$ for straw $\mathrm{N}$ - uptake Increases due to $2-\mathrm{m} 3-\mathrm{m}$, and $4-\mathrm{m}$ spacing ditch method were $49.0 \% 33.2 \%$ and $25.7 \%$, respectively for uptake in grains and $57.7,36.0$ and $25.2 \%$, respectively for $\mathrm{N}$ - uptake in rice straw. Increased $\mathrm{N}$ - uptake of rice grain and straw by application of rice straw residue also has been reported by Kaewpradit et al. (2009).

Egypt. J. Soil Sci. 54, No. 1 (2014) 
RATES AND METHODS OF RICE STRAW APPLICATION...

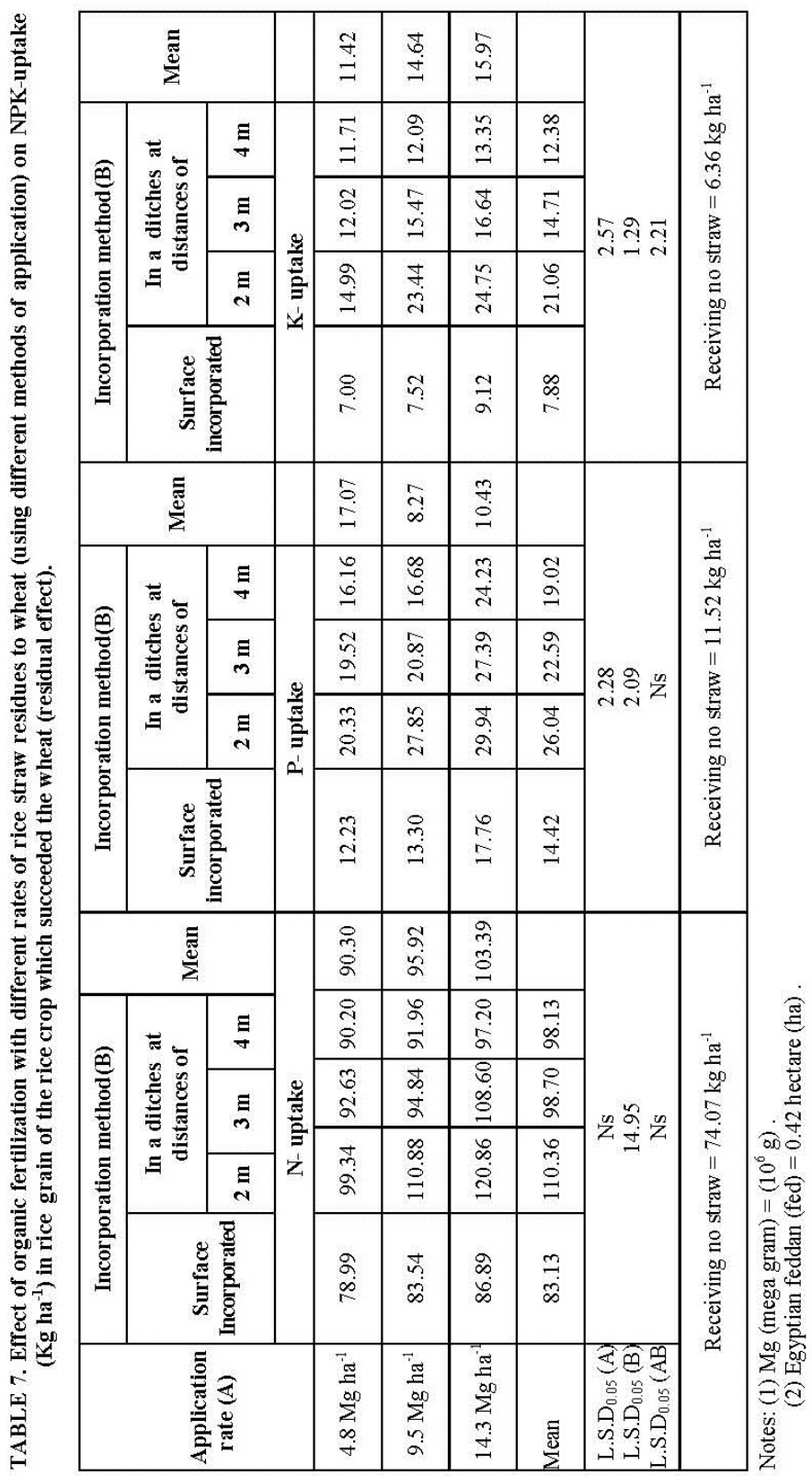

Egypt. J. Soil Sci. 54, No. 1 (2014) 


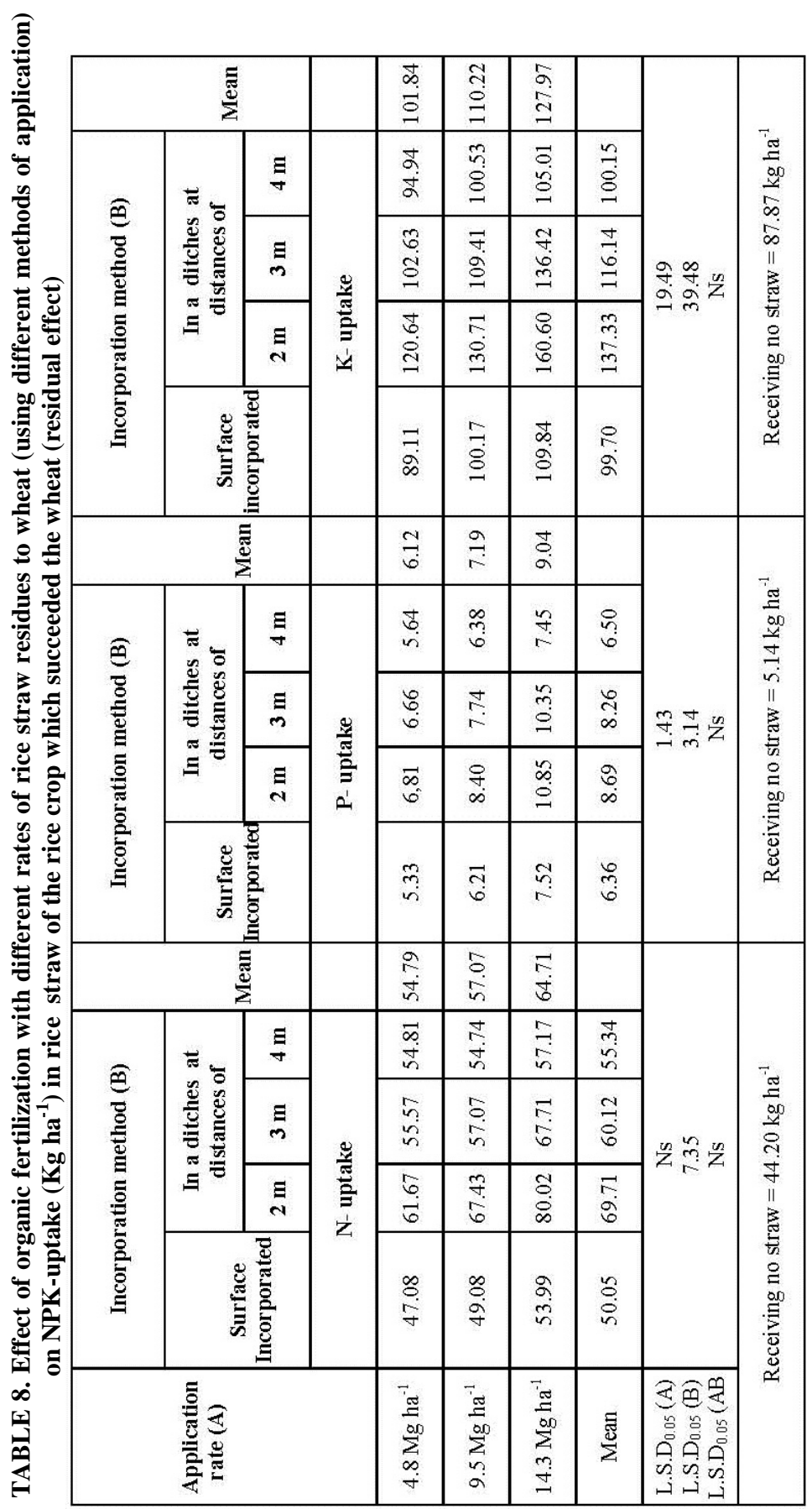

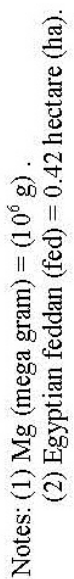

Egypt. J. Soil Sci. 54, No. 1 (2014) 
For grain protein content, data in Table 6 show higher protein content in treatments of the surface incorporation as well as those of the ditch method, particularly those of the 2 and $3 \mathrm{~m}$ distance as compared with content in the nostraw application. Contents in the ditch method were greater than in the surface application method. Contents increased with increasing straw -application rate. Average increases for the $1^{\text {st }} 2^{\text {nd }}$ and $3^{\text {rd }}$ rates were $12.8,15.4$ and $19.6 \%$, respectively. The ditch method was superior to the surface application method by averages of $17.9,10.5$. and 6.7 for the 2-, 3- and 4- $\mathrm{m}$ distance, respectively. The greater the distance between ditches, the less contents of protein

With respect to $\mathrm{P}$ - uptake, increases due to $1^{\text {st }}, 2^{\text {nd }}$ and $3^{\text {rd }}$ rates of application averaged $48.1,70.9$ and $115.5 \%$, respectively for uptake in grains, $19.0,39.8$ and $75.9 \%$, respectively for uptake in rice straw. The ditch method gave greater $\mathrm{p}$ - uptake than the surface method. The increases due to the surface method, averaged $25.0 \%$ for grains P- uptake and $23.6 \%$ for straw P- uptake Increases due to $2-\mathrm{m} 3-\mathrm{m}$ and $4-\mathrm{m}$ spacing ditch method were $126.0 \%$, $96.9 \%$ and $65.1 \%$, respectively for uptake in grains and 69.0, 60.7 and 26.4\%, respectively for uptake in rice straw. These results are similar to those obtained by Sharma and Parasad (2002), who found that incorporation of crop residue resulted in building up organic $\mathrm{C}$ and increased $\mathrm{P}$ uptake by rice.

Regarding $\mathrm{K}$ uptake in rice (grain and straw), data in Table 6 show that all treatments recorded greater values than control. Increases due to $1^{\text {st }}, 2^{\text {nd }}$ and $3^{\text {rd }}$ rates of application averaged $79.8,143.5$ and $151.3 \%$, respectively for uptake in grains; $15.9,25.4$, and $45.6 \%$, respectively for uptake in rice straw. The ditch method gave greater K- uptake than the surface method. The increases due to the surface method, averaged $24.0 \%$ for grains K- uptake and $13.5 \%$ for straw $\mathrm{K}$ - uptake Increases due to 2- $\mathrm{m}, 3-\mathrm{m}$ and 4- $\mathrm{m}$ spacing ditch method were $231.5 \% 131.5 \%$ and $94.8 \%$, respectively for uptake in grains and 56.3, 33.7 and $13.98 \%$, respectively for uptake in rice straw. These results are in agreement with those obtained by Prasad and Sinha (2000) and Saha et al. (2009).

\section{Overall assessment of response to rice straw application}

Applying rice straw gave negative response to the crop of wheat to which it was applied. This is an indication of removal of available nutrients to soil micro-organisms which must have been active in removing soluble $\mathrm{N}$ for building their bodies (i.e., immobilizing $\mathrm{N}$ ) due to abundant amounts of energy organic materials (the rice straw of the wide $\mathrm{C}: \mathrm{N}$ ratio). However, following several months of being in the soil, the rice straw must have undergone intensive decomposition, narrowing its $\mathrm{C}$ : $\mathrm{N}$ ratio due to consuming energy rich components. This would lead to a net mineralization of organic $\mathrm{N}$-particularly the $\mathrm{N}$ in the dead micro-organisms. For this reason, the residual effect of showed positive response and increased yield and NPK uptake of the rice crop which succeeded to wheat crop. 
Soil bulk density

Generally, application of rice straw to the soil decreased bulk density in all treatments (Table 9). These results are in agreement to those obtained by Bhagat and Verma (1991), He and Liu (1992), Prasad and Sinha (2000) and Bhagat et al. (2003) who stated that lower soil bulk density and higher porosity were realized after the application of rice straw and organic residues. Bulk density responded significantly to treatments (Table 7). Regarding to the rate of application of rice straw, data show that bulk density decreased when the rate increased. The lowest value $\left(1.26 \mathrm{gm} \mathrm{cm}^{-3}\right)$ was realized at $1^{\text {st }}$ rate of application.

For methods of application, the results indicate that ditch method gave lower bulk density than surface method. Ditches at $2 \mathrm{~m}$ distance showed an average of $1.27 \mathrm{Mg} \mathrm{m}^{-3}$ while that of surface treatment gave an average of $1.30 \mathrm{Mg} \mathrm{m}^{-3}$.

NPK and organic matter in soil

Different rice straw treatments showed positive residual effects on soil contents of NPK and organic matter and recorded greater values than the not receiving straw residue treatment (Table 10). Increases obtained occurred with increasing the rate of organic residues in all methods of application. The ditches method gave higher values than the surface incorporation method. Higher values were obtained at $3^{r d}$ rate which gave average increases of 11.9, 12.1, 26.7 and $40.4 \%$ for N, P, K and organic matter contents of soil compared to the no- straw treatment. These findings are in agreement with those obtained by Bhagat and Verma (1991), Sharma Prasad and (2002) and Kaewpradit et al. (2009) who reported that the practice of residue incorporation may be better to sustain arable soils and represents an interesting method of managing soil fertility and the soil organic matter content is related strongly to the amount of residues added and the organic matter is regarded as the ultimate source of nutrients and microbial activity in the soil.

With respect to the effect of methods of application, data show that the ditch method surpassed the surface incorporation method. The 2-, 3- and 4- $\mathrm{m}$ distance treatments showed average increases over the surface application as follows: $24.19,16.93$ and $12.1 \%$, respectively for $\mathrm{N}, 23.78,15.0$ and $9.33 \%$ respectively for $\mathrm{P}, 50.6,31.5$ and $17.9 \%$, respectively for $\mathrm{K}$ and $24.6,17.3$ and $8.2 \%$ for organic matter

\section{Conclusion}

The study assessed the use of rice straw applied by surface method compared with application in ditchesat rates ranging from 4.8 to $14.3 \mathrm{Mg} \mathrm{ha}^{-1}$. Results show that application of rice straw to wheat crop in a ditches of $4 \mathrm{~m}$ distance between each other resulted in wheat grain yield which is relatively equal to the conventional yield produced by the farmers using no rice straw. The residual effect of straw application for both the two methods of application increased rice grain yield. Bulk density was decreased whereas porosity as well as NPK and organic matter contents were increased by straw application following rice.

Egypt. J. Soil Sci. 54, No. 1 (2014) 
RATES AND METHODS OF RICE STRAW APPLICATION...

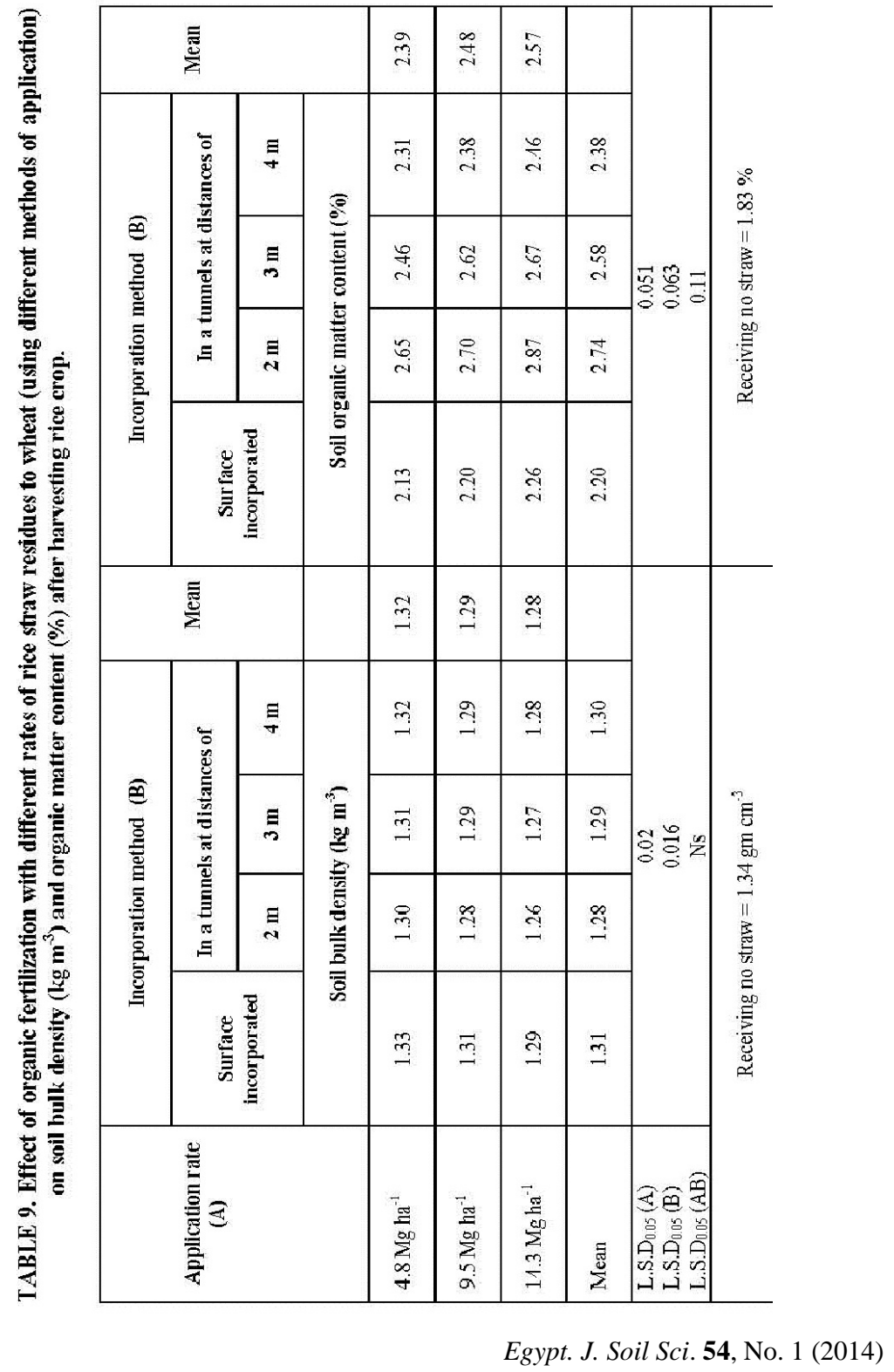




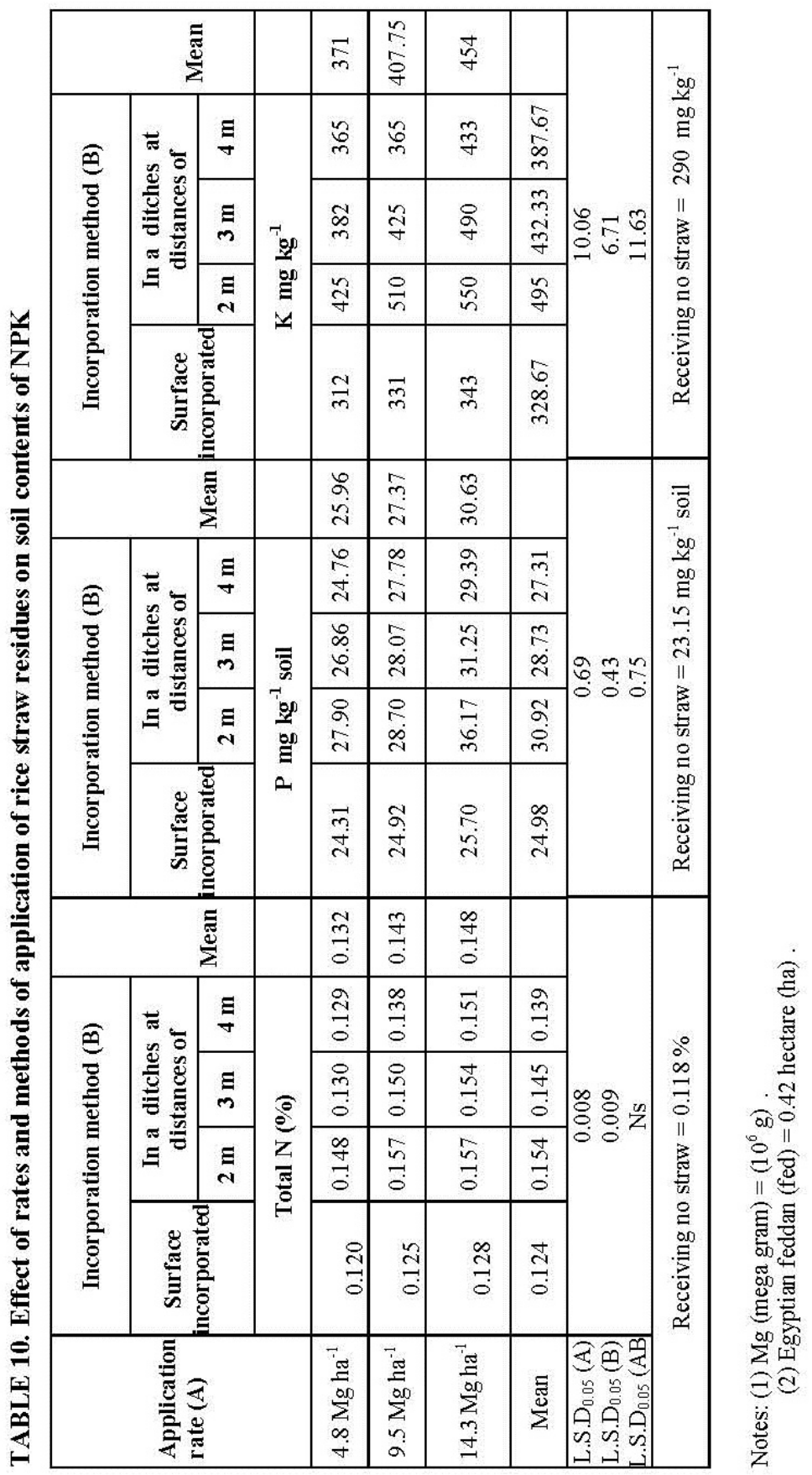

Egypt. J. Soil Sci. 54, No. 1 (2014) 
Recycling rice straw residue in long - term wheat - rice system in ditches of $4 \mathrm{~m}$ distance between each other at any rate of application will improve soil physical, chemical and biological properties and increase crop productivity particularly following long time after application. Thus would enable the farmers to get rid of rice straw in a safety manner to avoid the problem of burning it which not only lead to loss of huge biomass but also cause environmental pollution. In addition, long - term application of rice straw residue may reduce the use of inorganic fertilizers and then decrease soil pollution.

Acknowledgement :This research was funded by the research contract signed on 15/6/ 2009 with Zagazig University through the Competitive Projects Program funded by the University.

\section{References}

Azam, F., Lodhi, A. and Ashraf, M. (1991) Availability of soil and Fertilizer N to wetland rice following wheat straw amendment. Biol.and Fert. of Soils 11:97 - 100.

Azam, F., Ashraf, M. and Lodhi, A. (1993) Relative significance of soil and fertilizer nitrogen to nitrogen nutrition of wheat following rice straw amendment. Pak. J. Sci. 7: $50-54$

Bhagat, R.M., Bhardwaj, A.K. and Sharma, P.K. (2003) Long-term effect of residue management on soil physical properties, water use and yield of rice in north western India. J. Indian Soc. Soil Sci. 51: 111-117.

Bhagat, R.M. and Verma, T.S. (1991) Impact of rice straw management on soil physical propertiesand wheat yield. Soil Sci. 152: 108-115.

Bird, J.A., Horwath, W.R., Eagl, A.J. and Van. Kessel, C. (2001) Immobilization of fertilizer nitrogen in rice : effects of straw management practices. Soil Sci. Soc. Am. J. $65: 1143-1152$.

Bunt, A.C. (1988) Media and mixes for container-grown plants. Unwin Hyman, London.

Can, J. (1999) Crop residue and fertilizer management effects on nutrient use and barley production. Soil Sci. 79: 389-394.

Cassman, K.G., Kroppf, M.J., Gaunt, J. and Peng, S. (1993) Nitrogen use efficiency of rice reconsidered: what are are the key constrains? Plant Soil 155/156: 359-362.

Chapman, H.D and Pratt, P.F. (1961) "Methods of Analysis for Soils, Plant and Water", Div. of Agric., Sci. Univ. of Calif., USA.

Chesire, M.V., Bedrock, C.N., Williams, B.L., Chapman, S.J., Solntseva, I. and Thomsen, I. (199) The immobilization of nitrogen by straw decomposition in soil. European Journal of Soil Science 50: 329 - 341. 
Elliot, L., Cochran, VL. and Papendick, RI. (1981) Wheat residues and nitrogen placement effects on wheat growth in green house. Soil Sci. 131: 48-52.

Gong, W., Yan, X. Wang, J. Hu, T. Gong, Y. (2009) Long-term manure andfertilizer effects on soil organic matter fractions and microbes under a wheat-maize cropping system in northern China. Geoderma 149: 318-324

He, N. and Liu, Z. (1992) Effect of organic and chemical fertilizers on the grain yields and soil properties. Proceeding of International Symposium on Nutrient Management for Sustained Productivity, Vol. II, pp. 130-132, Punjab Agric. Univ., Ludhiana, India.

Jimenes, M.P, Hora, A.M., Pruzzo, L. and Palma, R.M. (2002) Soil quality: a new index based on microbiological and biochemical parameter. Biology and Fertility of Soils 35: 302-306.

Kaewpradit, W., Toomsan, B., Cadisch, G., Vityakon, P., Limpinuntana, V., Saenjan, P., Jogloy, S. and Patanothai, A. (2009) Mixing groundnut residues and rice straw to improve rice yield and $\mathrm{N}$ use efficiency. Field Crops Res. 110: 130-138.

Kaur, N. and Benipal, D.S. (2006) Effect of crop residue and farmyard manure on K forms on soils of long term fertility experiment. Indian J. Crop Sci. 1(1-2): 161-164.

Liu, E., Yan, C., Mei, X., He, W., Bing, S.H., Ding, L., Liu, Q., Liu, S. and Fan, T. (2010). Longterm effect of chemical fertilizer, straw, and manure on soil chemical and biological properties in northwest China . Geoderma 158:173- 180.

Piper, C.S. (1950) “Soil and Plant Analysis”, Academi Press, New York,USA.

Powel, J.M. and Unger, P.W. (1997) Alternatives to crop residues as soil amendments In: "Crop Resides in Sustainable Mixed Crop/Livestock Farming Systems", C. Renard, (Ed.), pp. 215-239, ICRISAT, India and ILRI, Kenya.

Prasad, B. and Sinha, S.K. (2000) Long-term effects of fertilizers and oganic manures on crop yields, nutrient balance and soil properties in rice- wheat cropping system in bihar. In: "Long-term Soil Fertility Experiments in Rice- Wheat Cropping Systems", I.P., Abrol, K.F., Bronson, J.M. Duxbury and R.K. Gupta, (Ed.), RiceWheat Consortium Paper Series 6. New Delhi, India: Rice-Wheat Consortium for the Indo-Gangetic Plains.

Qian, P. and Schoenau, J. (2002) Availability of nitrogen in solid manure amendments with different C: N ratios. Can. J. of Soil Sci. 82: (2) 219-225.

Saha, P.K., Miah, M.A.M., Hossain, A.T.M.S., Rahman, F. and Saleque, M.A. (2009) Contribution of rice straw to potassium supply in rice fallow-rice cropping pattern. Bangladesh J. Agric. Res. 34 (4): 633-643.

Sarwar, G., Schmeisky, H., Hussain, N., Muhammed, S., Ibrahm M. and Ehsan Safdar (2008) Improvement of soil physical and chemical properties with compost application in rice-wheat cropping system. Pak. J. Bot. 40 (1): 275-282. 
Sharma, S.N. and Prasad, R. (2008) Effect of crop-residue management on the production and agronomic nitrogen efficiency in a rice-wheat cropping system. J. of Pl. Nutr. and Soil Sci. 171 (2): 295-302.

Sharma S.N. and Prasad, R. (2002) Effect of crop residue with and without a culture of cellulolytic fungi on yield, NPK uptake and soil fertility rice -wheat cropping system. Archives of Agron. and Soil Sci 48 (4): 363-370.

Sidhu, B.S. and Beri, V. (1989) Effect of crop residue management on the yields of different crops and on soil properties. Biological Wastes 27: 15-27.

Soon, Y.K. (1999) Crop residue and fertilizer management effects on nutrient use and barley production. Can. J. Soil Sci. 79: 389-394.

27. Shindo, H. and Nishio, T. (2005) Immobilization and remineralizationof folloing addition wheat straw into soil: determination of gross $\mathrm{N}$ transformationrates by ${ }^{15} \mathrm{~N}-$ ammonium isotope dilution teqnique. Soil Biol. Biochem. 37: 425-432.

Tawfik, M.M. and Gomaa, A.M. (2005) Effect of organic and biofertilizer on growth and yield of wheat plants. Egypt. J. Agric. Res. 2 (2): 711-725.

Van Kessel, J.S., Reeves, J.B. and Meisinger, J.J. (2000) Nitrogen and carbon mineralization of potential manure components. Journal Environmental Qualiyy 29: $1669-1677$.

Varinderpal-Singh, Dhillon, N. and Brar, B. (2006) Effect of incorporation of crop residues and organic manures on adsorption/desorption and bio-availability of phosphate. Nutrient Cycling in Agroecosystems 76 (1) : 95-108 (14).

Verma, T.S. and Bhagat, R.M. (1992) Impact of rice straw management practices on yield, nitrogen uptake and soil properties in a wheat-rice rotation in northern India. Fertilizer Research 33: 97-106.

Yaduvanshi, N.P.S. and Sharma, D.R. (2008) Tillage and residual organic manures/chemical amendment effects on soil organic matter and yield of wheat under sodic water irrigation. Soil \& Tillage Research 98: 11-16.

Zeidan, M.S., Hozayn, M. and El- Krammany, M.F. (2005) Effect of different organic fertilizer sources and levels on growth and yield of wheat (Triticum aestivum L.) in sandy soil. Egypt. J. Agric. Res. 2 (2), 643.

(Received 9/1/2013; accepted 14/12/2014) 


\title{
طرق ومعدلات إضافة قش الأرز إلى محصول القمح والأرز

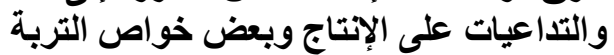

\author{
أشرف محمد جودة عويس ، محمود محمد صبح ، محمد حامد عامر و محمد \\ جودة محمد خليل \\ قسم الأر اضى و المباة ـ كلية التكنولوجيا و التنمية ـ جامعة الزقازيق ـ الزقازيق -
}

أجريت تجربتين واحدة على محصول القمح والثانية على محصول الأرز الذي الذي

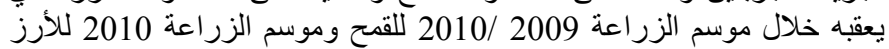

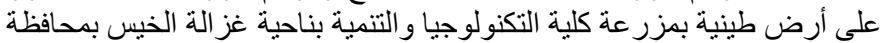

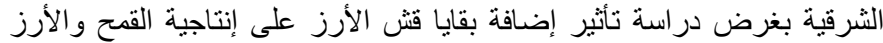

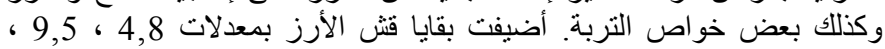

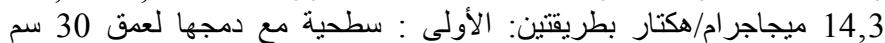
(طبقة الحرث) ، الثانية : في أنفاق بعمق 40 سم على مسافات 2كات 2، 3 ، 4 متر من

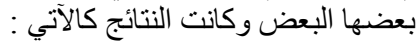

أو لا: تأثثير إضافة بقابا قش الأرز إلى التربة على المحصول الحالي ( القمح)

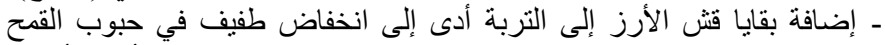

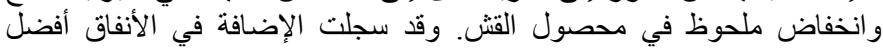

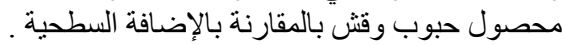

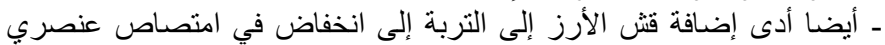

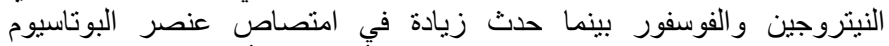

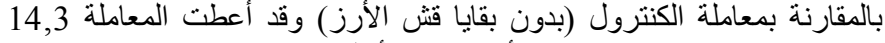

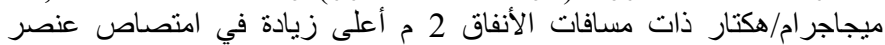

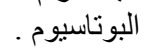

ثانيا: التأثير المتبقي على المحصول اللاحق (الأرز)

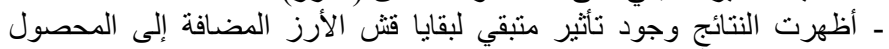

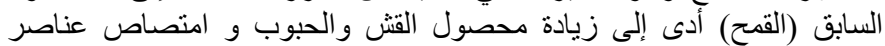

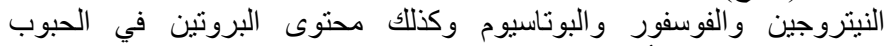

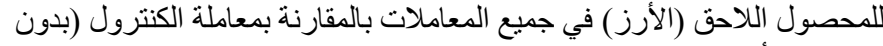
بقايا قش الأرز).

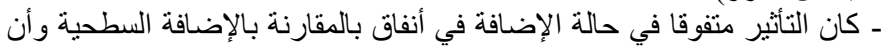
أفضل نتائج تم الحصول عليها في معاملة الأنفاق 2م ومعدل إضافة الإنة 14,3 ميجاجر ام / هكتار .

$$
\text { ثالثا: التأثنير المتبقي على بعض خو اص التبر التربة }
$$

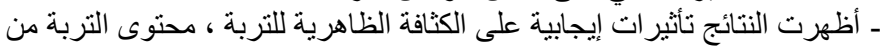

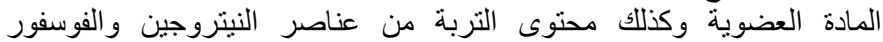

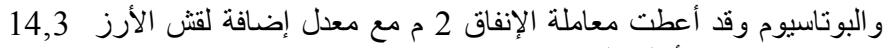
ميجاجر ام / هكتار أعلى النتائج . 